PRACE NAUKOWE UNIWERSYTETU EKONOMICZNEGO WE WROCLAWIU

Wyzwania dla spójności Europy -

ISSN 1899-3192

społeczeństwo, granice, solidarność

e-ISSN 2392-0041

\title{
Tatyana Andreeva
}

The Baltic International Academy, Riga

e-mail: andrejevats@inbox.lv

\section{TAXATION METHODS AS A SOLUTION \\ OF SOCIAL PROBLEMS IN LATVIA}

\section{METODY PODATKOWE \\ JAKO SPOSÓB ROZWIĄZYWANIA \\ PROBLEMÓW SPOLECZNYCH NA LOTWIE}

DOI: $10.15611 /$ pn.2017.465.01

\begin{abstract}
Summary: The article is devoted to the study of the problems of state regulations in the field of taxation. The purpose of this article is to analyse distributing and stimulating functions of taxes taking into account the actual situation in the discussed field. The article analyzes such issues as the increase of contributions in social insurance, changes in personal income tax, the use of stimulation function of value added tax. Special attention is paid to the introduction of differentiated non-taxable allowance and tax of solidarity in Latvia. A differential personal allowance means that not all taxpayers will have the same level of personal allowance, as its level will be set according to the taxpayer's level of income. The purpose of the introduction of solidarity tax is to reduce the regressivity of the taxation for the recipients of high levels income.
\end{abstract}

Keywords: taxes, tax system, social insurance contributions, personal income tax, value added tax, differentiated non-taxable allowance, solidarity tax.

Streszczenie: Artykuł poświęcony został analizie problemów regulacji państwowej w zakresie podatków. Celem jego jest analiza funkcji dystrybucyjnych i stymulujących podatków $\mathrm{z}$ uwzględnieniem aktualnej sytuacji $\mathrm{w}$ omawianym obszarze. W artykule analizowane są takie kwestie, jak: wzrost udziału zabezpieczenia społecznego, zmiany w podatku PIT, wykorzystanie funkcji stymulacyjnych podatku od wartości dodanej (VAT). Szczególna uwaga została poświęcona wprowadzeniu zróżnicowanych zwolnień podatkowych oraz podatku solidarnościowego na Łotwie. Zróżnicowane zwolnienia podatkowe dla podatników indywidualnych oznaczają, że nie wszyscy podatnicy będą mieli ten sam poziom zwolnień podatkowych. Uprawnienia każdego podatnika do zwolnień będą ustalane w oparciu o wysokość ich dochodów. Celem wprowadzenia podatku solidarnościowego jest redukcja regresji podatkowej występującej w przypadku osób uzyskujących wysoki poziom dochodów.

Słowa kluczowe: podatki, system podatkowy, udział zabezpieczenia społecznego, podatek od dochodów osobistych (PIT), podatek od wartości dodanej (VAT), zróżnicowane zwolnienia podatkowe, podatek solidarnościowy. 


\section{Introduction}

In modern conditions the economic, social and political factors as well as the processes of globalization have a significant impact on the change of tax systems. The globalization of the world economy, integration processes and the creation of international corporations create conditions for a unified approach to the formation of the tax systems that consider the global theoretical and practical experience, developed world economic processes, the mobility of capital and the means of production. Social function is one of the most important functions of the state in modern conditions. The main content of social function of the state consists in the prevention of social tension in society and the alignment of socio-economic situation of people in the development of health, education and culture system.

The performance of social function by the Latvian state is related to the solution of the following problems:

- equalizing income inequality of different population groups,

- increasing social security of the poor,

- stimulating investment into human development.

To solve these challenges the state may use different methods. Among them a significant role is played by the tax system of the country having the developed stimulating and distributive functions.

The stimulating function consists in the formation of certain development incentives for the targeted categories of taxpayers. This feature is implemented through a system of tax benefits for these categories and activities (preferential tax regimes, reduced tax rates, tax deferrals, various releases, deductions, etc.). Distributive (social) function expresses the socio-economic essence of taxes as a specific instrument of distributive relations. This feature provides a solution to a number of socio-economic problems, which are outside the market self-regulation. Taxes and tax system are the means of solving socio-economic problems, allowing to redistribute the social product among various groups of the population in order to reduce social inequalities and to maintain social stability. The modern tax system of the Republic of Latvia can be considered as effective only if it is focused on the formation of stable functioning of social system.

The work objective is to analyse the distributive and stimulating function of taxes, taking into account the current situation in solving social problems in Latvia (on the example of social security contributions, personal income tax, VAT, solidarity tax). The article uses a systematic approach, the method of comparing statistical data from EU countries, different periods and different indicators, studying their dynamics.

\section{The growth of social insurance contributions}

The most important trend in the development of tax systems in the European Union countries is the increase in social security contributions. Currently, on average the incomes on them in the European countries are almost equal to the proceeds from the 
personal income tax. In a number of the states, including Latvia, these payments have already exceeded receipts from personal income tax. This trend reflects such global changes in the European Union as the aging of the population, decrease in birth rate, increase in the number of single parents, poor health and the growth of unemployment. As a rule, social security payments are calculated at the rates of salary and the tax burden is shared between an employee and an employer in a certain ratio.

Table 1 shows the rate of social security payments applicable in the EU member states in 2014.

Table 1. Insured and employer contribution rates, 2014 (in percent)

\begin{tabular}{|l|c|c|c|}
\hline \multicolumn{1}{|c|}{ Country } & Employer & Insured person & Total \\
\hline Austria (AT) & 25.15 & 17.2 & 42.35 \\
\hline Belgium (BE) & 24.8 & 13.07 & 37.87 \\
\hline Bulgaria (BG) & 17.8 & 12.9 & 30.7 \\
\hline Croatia (HR) & 15.2 & 20.0 & 35.2 \\
\hline Cyprus (CY) & 7.8 & 7.8 & 15.6 \\
\hline Czech Republic (CZ) & 34 & 11 & 45 \\
\hline Denmark (DK) & - & 8 & 8 \\
\hline Estonia (EE) & 34 & 4 & 38 \\
\hline Finland (FI) & 22.19 & 8.41 & 30.60 \\
\hline France (FR) & 37.5 & 13.2 & 50.7 \\
\hline Germany (DE) & 20.575 & 20.175 & 40.75 \\
\hline Greece (EL) & 23.60 & 12.05 & 35.65 \\
\hline Hungary (HU) & 27 & 16 & 43 \\
\hline Ireland (IE) & 4.25 & 4 & 8.25 \\
\hline Italy (IT) & 33.68 & 9.19 & 42.87 \\
\hline Latvia (LV) & 23.59 & 10.50 & 34.09 \\
\hline Lithuania (LT) & 31.17 & 9 & 40.17 \\
\hline Luxembourg (LU) & 11.95 & 12.70 & 24.65 \\
\hline Malta (MT) & 10.0 & 10.0 & 20.0 \\
\hline Netherlands (NL) & 19.7 & 22.70 & 41.77 \\
\hline Poland (PL) & 19.38 & 22.71 & 42.09 \\
\hline Portugal (PT) & 23.75 & 11 & 34.75 \\
\hline Romania (RO) & 28.0 & 16.5 & 44.5 \\
\hline Slovakia (SK) & 33.2 & 13.4 & 46.6 \\
\hline Slovenia (SI) & 16.63 & 22.1 & 38.73 \\
\hline Spain (ES) & 31.08 & 7.25 & \\
\hline Sweden (SE) & 31.42 & 11.1 & \\
\hline United Kingdom (UK) & 13.8 & & \\
\hline & $23-28.9$ & \\
\hline & & & \\
\hline
\end{tabular}

Source: [Social Security... 2014, pp. 23-28]. 
The provided data show that in relation to social taxes and contributions, the specificity of national tax regulation is clearly manifested [Andreeva 2014, pp. 380$-381]$.

As an example of this kind it is possible to give the financing scheme of social security programs adopted in Denmark. In accordance with the scheme, the social security contributions are subject to payment by the worker at the rate of $8 \%$ of the total income derived from employment. Employers in Denmark in general, do not pay social security contributions. In such countries as Cyprus and Malta, employers and employees pay social contributions in equal proportions. Nearly equal proportions of social contributions are paid by employers and employees in Germany, Ireland and Luxembourg. At the same time in the majority of the European Union countries, the prevailing part of social security contributions is calculated and paid by the employer.

The main normative act of Latvia in the field of social insurance is the Law "On State Social Insurance". The law defines the general principles of the state social insurance, and also regulates its financial and organizational structure.

In Latvia there are six types of social insurance [Law "On State...", Article 14]:

- state pension insurance,

- insurance in the case of unemployment,

- insurance against accidents at work and occupational diseases,

- disability insurance,

- maternity and sickness insurance,

- parents' insurance.

Rates of social contributions for persons, which are subject to social insurance, as well as rates on certain types of public insurance are set annually by the regulations of Cabinet of Ministers of Latvian Republic [Law “On State...", Article 18]. The rate of mandatory contributions, if the employee is insured for all types of social insurance, amounted to $34.09 \%$ in $2016,23.59 \%$ of which is payed by the employer and $10.50 \%$ by the employee.

The dynamics of social insurance contributions revenue in the Consolidated General Budget of Latvia is presented in Table 2.

Table 2. State social security contributions revenue

\begin{tabular}{|l|r|r|r|r|}
\hline & 2013 & 2014 & 2015 & 2016 \\
\cline { 2 - 5 } & fact & fact & fact & \multicolumn{1}{c|}{ plan } \\
\hline Social security contributions, mln. euro & 1980.8 & 1976.1 & 2048.7 & 2108.9 \\
\hline$\%$ of tax revenues & 30.8 & 29.6 & 29.2 & 28.6 \\
\hline
\end{tabular}

Source: [Law "On the State Budget...”].

Social security contributions represent the largest share of tax revenues in the state budget of Latvia and they amounted to $29.3 \%$ of tax revenues in 2015. In 2015, revenues from social security contributions amounted to 2048.7 billion euros, which 
is 72.6 billion euros more than in $2014(+3.7 \%)$. In accordance with the Law "On the State Budget for 2016", social security contributions are planned in the amount of 2108.9 million euros. It is 60.2 million euros more than in $2015(+2.9 \%)$.

Social insurance is an integral part of the state social security system. The group of social security payments requires special attention in terms of methodological and organizational study of the mechanism of their collection and use, control over spending and justification of rates.

\section{Changes in the Personal income tax}

Personal income tax is charged in all countries of the European Union. Differences in certain states are usually associated with the features of the definition of certain tax elements. Most European Union countries apply progressive rates of personal income tax. Only 5 countries of the $28 \mathrm{EU}$ Member States, use a proportional scale: Latvia, Lithuania, Estonia, Bulgaria and Romania. In recent years there is a steady downward trend in the maximum income tax rates in the EU. However, even after lowering, the marginal rate of income tax from the population remains quite high (Table 3).

Table 3. Top personal income tax rates, in $\%$

\begin{tabular}{|l|c|c|c|c|}
\hline \multicolumn{1}{|c|}{ Country } & 2000 & 2013 & 2014 & 2015 \\
\hline \multicolumn{1}{|c|}{1} & 2 & 3 & 4 & 5 \\
\hline Austria (AT) & 50.0 & 50.0 & 50.0 & 50.0 \\
\hline Belgium (BE) & 60.6 & 53.8 & 53.8 & 53.8 \\
\hline Bulgaria (BG) & 40.0 & 10.0 & 10.0 & 10.0 \\
\hline Croatia (HR) & 41.3 & 47.2 & 47.2 & 47.2 \\
\hline Cyprus (CY) & 40.0 & 35.0 & 35.0 & 35.0 \\
\hline Czech Republic (CZ) & 32.0 & 22.0 & 22.0 & 22.0 \\
\hline Denmark (DK) & 62.3 & 55.6 & 55.6 & 55.8 \\
\hline Estonia (EE) & 26.0 & 21.0 & 21.0 & 20.0 \\
\hline Finland (FI) & 54.0 & 51.1 & 51.5 & 51.6 \\
\hline France (FR) & 59.0 & 50.3 & 50.3 & 50.3 \\
\hline Germany (DE) & 53.8 & 47.5 & 47.5 & 47.5 \\
\hline Greece (EL) & 45.0 & 46.0 & 46.0 & 48.0 \\
\hline Hungary (HU) & 44.0 & 16.0 & 16.0 & 16.0 \\
\hline Ireland (IE) & 44.0 & 48.0 & 48.0 & 48.0 \\
\hline Italy (IT) & 45.9 & 47.3 & 47.9 & 48.9 \\
\hline Latvia (LV) & 25.0 & 24.0 & 24.0 & 23.0 \\
\hline Lithuania (LT) & 33.0 & 15.0 & 15.0 & 15.0 \\
\hline Luxembourg (LU) & 47.2 & 43.6 & 43.6 & 43.6 \\
\hline Malta (MT) & 35.0 & 35.0 & 35.0 & 35.0 \\
\hline Netherlands (NL) & 60.0 & 52.0 & 52.0 & 52.0 \\
\hline
\end{tabular}


Tabela 3, cd.

\begin{tabular}{|l|c|c|c|c|}
\hline \multicolumn{1}{|c|}{1} & 2 & 3 & 4 & 5 \\
\hline Poland (PL) & 40.0 & 32.0 & 32.0 & 32.0 \\
\hline Portugal (PT) & 40.0 & 56.5 & 56.5 & 56.5 \\
\hline Romania (RO) & 40.0 & 16.0 & 16.0 & 16.0 \\
\hline Slovakia (SK) & 42.0 & 25.0 & 25.0 & 25.0 \\
\hline Slovenia (SI) & 50.0 & 50.0 & 50.0 & 50.0 \\
\hline Spain (ES) & 48.0 & 52.0 & 52.0 & 46.0 \\
\hline Sweden (SE) & 51.5 & 56.7 & 56.9 & 57.0 \\
\hline United Kingdom (UK) & 40.0 & 45.0 & 45.0 & 45.0 \\
\hline EU-28 & $\mathbf{4 4 . 6}$ & $\mathbf{3 9 . 4}$ & $\mathbf{3 9 . 5}$ & $\mathbf{3 9 . 3}$ \\
\hline EA-19 (Euro Area) & $\mathbf{4 5 . 2}$ & $\mathbf{4 2 . 3}$ & $\mathbf{4 2 . 3}$ & $\mathbf{4 2 . 1}$ \\
\hline
\end{tabular}

Source: [Tax Reforms..., p. 111].

As it can be seen in Table 3, the highest rate of personal income tax in 2015 was in Sweden - 57.0\%, Portugal - 56.5\%, Denmark - 55.8\%, Belgium - 53.8\%, the Netherlands $-52.0 \%$, Finland $-51.6 \%$, France $-50.3 \%$, Austria and Slovenia $50.0 \%$. In Latvia since 2000 to 1 January 2013, the rates of personal income tax declined from $25 \%$ to $24 \%$, and to January 1, 2015 to $23 \%$. The rate of personal income tax was $23 \%$ in 2016 . The dynamics of personal income tax income in the Consolidated General Budget of Latvia is presented in Table 4.

Table 4. Personal income tax revenue

\begin{tabular}{|l|c|r|r|r|}
\hline & 2013 & 2014 & 2015 & 2016 \\
\cline { 2 - 5 } & fact & fact & fact & plan \\
\hline Personal income tax, mln. euro & 1333.0 & 1385.2 & 1436.9 & 1530.9 \\
\hline$\%$ of tax revenues & 20.7 & 20.7 & 20.5 & 20.8 \\
\hline
\end{tabular}

Source: [Law "On the State Budget...”].

The data in Table 4 show an increase in revenues from personal income tax for the period under review. The share of personal income tax in 2015 amounted to $20.5 \%$ of tax revenues. In 2015, revenues from personal income tax amounted to 1436.9 billion euros, which is EUR 51.7 billion more than in $2014(+3.7 \%)$. In accordance with the Law "On the State Budget for 2016" proceeds from the personal income tax are planned in the amount of 1530.9 million euros. This is 94 billion euros more than in $2015(+6.5 \%)$. The increase in revenues from the personal income tax is connected with the growth of employment, rising wages, as well as measures taken to combat the shadow economy. On January 1, 2016 the minimum wage in Latvia increased from 360 euros to 370 euros. In 2015, the average salary in Latvia amounted to 807.2 euros. According to the forecasts of the Ministry of Finance of Latvia, in 2016 the average salary should reach 847.6 euros, in $2017-894.2$, in 2018 - 943.4. When calculating the personal income tax a taxpayer has the right to use 
non-taxable minimum and privilege for dependents. From 1 January 2016 the privilege for a dependent, in comparison with 2015 increased by 10 euros and makes 175 euros per month, or 2,100 euros per year. The privilege is granted to one of the supporters for each dependent person. The law provides additional benefits for the disabled of I and II groups - 1848 euros per year, or 154 euros per month; for the disabled of group III - 1440 euros per year, or 120 euros per month; for the politically repressed persons and participants of the national resistance movement - 1848 euros per year, or 154 euros per month. In 2015, the non-taxable minimum made 75 euros per month, or 900 euros per year. Since January 1, 2016 the new system of nontaxable minimum calculation - differentiated payment - has been introduced. A differential personal allowance means that not all taxpayers will have the same level of personal allowance, as its level will be set according to the taxpayer's level of income. In 2015, all working Latvian tax residents had the same personal allowance of 75 euros a month. As from 2016, the Cabinet Regulation No 1 of 05.01.2016 proposes introducing differential personal allowance (DPA), which will stay at the same level on a monthly basis in 2016. The personal allowance for people on low wages (up to 380 euros a month) will grow over the coming years to reach 160 euros a month by 2020 . For people with medium wages (380-1000 euros) the personal allowance will be kept close to the existing level, while people with high salaries (over 1000 euros) will have a reduced level of personal allowance or none at all.

Why is differential personal allowance being introduced?

According to statistical indicators (the Gini coefficient) Latvia currently ranks second in the EU on inequality in pay. The purpose of introducing differential personal allowance is to ease the labour tax burden on the lower paid employees, thus mitigating income inequality. Lithuania, Romania, and Slovakia are examples of countries using differential personal allowance.

How will differential personal allowance apply?

Table 5. Criteria for introducing differential personal allowance, EUR/a month

\begin{tabular}{|l|c|c|c|c|c|}
\hline \multicolumn{1}{|c|}{ Criteria } & 2016 & 2017 & 2018 & 2019 & 2020 \\
\hline$P A_{\min }$ & 75 & 60 & 40 & 20 & 0 \\
\hline$P A_{\max }$ & 100 & 115 & 130 & 145 & 160 \\
\hline$T I_{\min }$ & 380 & 400 & 420 & 440 & 460 \\
\hline$T I_{\max }$ & 1000 & 1100 & 1200 & 1350 & 1500 \\
\hline Factor & 0.0403 & 0.0786 & 0.1154 & 0.1374 & 0.1538 \\
\hline$T I_{\min }$ & $\begin{array}{l}\text { the bottom limit of annual taxable income }\left(T I_{\min } \times 12\right) \text { up to which the maximum } \\
\text { annual personal allowance is applied }\end{array}$ \\
\hline$T I_{\max }$ & the top limit of annual taxable income $\left(T I_{\max } \times 12\right)$ up to which DPA is applied \\
\end{tabular}

Source: [Cabinet Regulation...]. 
An employer when computing the personal income tax charge every month currently applies the personal allowance on a monthly basis. After introducing differential personal allowance, the minimum personal allowance (PAmin) will apply on a monthly basis. People with low and medium wages will be able to recalculate their differential personal allowance and claim from the State Revenue Service a refund of any personal income tax they have overpaid through the annual income tax return on an annual basis. People with high salaries will get only PAmin.

The formula for computing differential personal allowance (DPA):

$$
\begin{gathered}
D P A=P A_{\text {max }}-\text { Factor } \times\left(T I-T I_{\text {min }}\right), \\
\text { Factor }=\left(P A_{\text {max }}-P A_{\text {min }}\right) /\left(T I_{\text {max }}-T I_{\text {min }}\right) .
\end{gathered}
$$

It is important to note that income from capital and capital gains will count towards annual income to avoid a situation where, for instance, a worker with the minimum wage claims the maximum personal allowance for the whole year and also receives a dividend or rental income at the end of year.

Differential personal allowance will not apply to people receiving pensions.

\section{Stimulating function of VAT}

The use of value-added tax (VAT) has great value for the quality of social situation in the country. The stimulating role of this tax is absolutely significant.

Table 6 shows the VAT rates applied in the countries - members of the EU in 2016.

As seen in Table 5, all EU Member States apply the standard rate of VAT. The highest standard rate is used in Hungary $-27 \%$ (the rate at this level is applied from 1 January 2012), in Denmark, Sweden and Croatia - 25\%, the lowest standard rate is in Luxembourg $-17 \%$. All countries, except Denmark, have reduced rates of VAT regarding certain categories of goods and services. Directives of EU allow to apply super reduced rates of VAT. These rates make less than 5\%. They are used in Spain (4\%), France (2.1\%), Ireland (4.8\%), Italy (4\%), and Luxembourg (3\%). All countries apply $0 \%$ rate (zero rate) to export sales and some other services. Currently in Latvia the VAT rates are set at the following sizes: $21 \%, 12 \%$ and $0 \%$. In Latvia, the standard VAT rate of $18 \%$ was established since 1995 to 2008; from 1 January 2009, it was increased to $21 \%$, and from 1 January 2011 , it rose to $22 \%$. Then it was decided to reduce the standard VAT rate. Thus, from July 1, 2012 to the present day, the standard rate of VAT in Latvia has accounted for $21 \%$. The lowered VAT rate of $12 \%$ is established in Latvia on some deliveries of goods and services which are socially important for the population. It should be noted that more than 20 types of goods and services, which the state considers necessary to provide at the lowest possible cost, are totally exempt from VAT. Thus, the state provides mass access to these goods and services. The legislation of the Republic of Latvia defined a large number of 
Table 6. VAT rates, 2016 (in percent)

\begin{tabular}{|c|c|c|c|}
\hline Country & Standard rate & Reduced rate & Super reduced rate \\
\hline Austria (AT) & 20 & $10 / 13$ & - \\
\hline Belgium (BE) & 21 & $6 / 12$ & - \\
\hline Bulgaria (BG) & 20 & 9 & - \\
\hline Croatia (HR) & 25 & $5 / 13$ & - \\
\hline Cyprus (CY) & 19 & $5 / 9$ & - \\
\hline Czech Republic (CZ) & 21 & $10 / 15$ & - \\
\hline Denmark (DK) & 25 & - & - \\
\hline Estonia (EE) & 20 & 9 & - \\
\hline Finland (FI) & 24 & $10 / 14$ & - \\
\hline France (FR) & 20 & $5.5 / 10$ & 2.1 \\
\hline Germany (DE) & 19 & 7 & - \\
\hline Greece (EL) & 23 & $6 / 13$ & - \\
\hline Hungary (HU) & 27 & $5 / 18$ & - \\
\hline Ireland (IE) & 23 & $9 / 13.5$ & 4.8 \\
\hline Italy (IT) & 22 & 10 & 4 \\
\hline Latvia (LV) & 21 & 12 & - \\
\hline Lithuania (LT) & 21 & $5 / 9$ & - \\
\hline Luxembourg (LU) & 17 & $8 / 14$ & 3 \\
\hline Malta (MT) & 18 & $5 / 7$ & - \\
\hline Netherlands (NL) & 21 & 6 & - \\
\hline Poland (PL) & 23 & $5 / 8$ & - \\
\hline Portugal (PT) & 23 & $6 / 13$ & - \\
\hline Romania (RO) & 20 & $5 / 9$ & - \\
\hline Slovakia (SK) & 20 & 10 & - \\
\hline Slovenia (SI) & 22 & 9.5 & - \\
\hline Spain (ES) & 21 & 10 & 4 \\
\hline Sweden (SE) & 25 & $6 / 12$ & - \\
\hline United Kingdom (UK) & 20 & 5 & - \\
\hline
\end{tabular}

Source: [VAT Rates..., p. 3].

transactions that are exempt from VAT. According to the purpose, these releases can be divided into two groups:

- social,

- economic.

The significance of exemptions of a social character is that they are designed to promote the development of certain services, relatively low level of prices for goods and social services and provision of tax benefits for certain groups that need state support. For example, the realization of vital medical equipment and some medical services, nursing services for the disabled and the elderly, funeral services, some educational services and institutions of culture and arts, scientific research, etc. are 
not subject to taxation. The group of a social character also includes such benefits as exemption from VAT of banking and insurance services, operations connected with the circulation of securities and some other exemptions. The exemptions of an economic character are applied for the stimulation of individual industries and economic processes. On the list of economic benefits can be distinguished exemptions from the VAT of cinema production works, the residential buildings maintenance, fire safety services and postal services. In each EU country entrepreneurs have benefits and eases on the application of VAT. However, there are differences. For example, food products are subject to VAT at reduced rates: Luxembourg $-3 \%$, in the Czech Republic, Portugal, Lithuania - 5\%, France $-5.5 \%$, Belgium - 6\%, Spain and Germany $-7 \%$. In the UK, Cyprus and Malta the prodecers of food products is exempt from VAT. The experience of European countries on the use of VAT demonstrates that in Latvia there are significant reserves on the application of the incentive function of this tax.

The dynamics of income of value added tax in the Consolidated General Budget of Latvia is presented in Table 7.

Table 7. Value added tax revenue

\begin{tabular}{|l|r|r|r|r|}
\hline & 2013 & 2014 & 2015 & 2016 \\
\cline { 2 - 5 } & fact & fact & fact & \multicolumn{1}{c|}{ plan } \\
\hline Value added tax, mln. euro & 1666.8 & 1803.7 & 1903.6 & 2024.9 \\
\hline$\%$ of tax revenues & 25.9 & 27.0 & 27.2 & 27.5 \\
\hline
\end{tabular}

Source: [Law "On the State Budget..."].

The data in Table 7 show a steady increase in revenues from value added tax for the period under review. The share of value added tax in 2015 amounted to $27.2 \%$ of tax revenues in the Consolidated General Budget of Latvia.

In 2015, revenues from the VAT amounted to 1903.6 billion euros, which is 99.9 billion euros more than in $2014(+5.5 \%)$. In accordance with the Law "On the State Budget for 2016", the revenues from VAT are planned in the amount of 2024.9 billion euros. It is 121.3 billion euros more than in $2015(+6.4 \%)$.

\section{Introduction of the solidarity tax}

The Law "On solidarity tax" came into force on January 1, 2016. The purpose of the solidarity tax introduction was to reduce the regressivity of the taxation for the recipients of high levels income and at the same time to provide the state with the basic budget income for the financing needs of the social protection of the population and the reduction of inequality. The law establishes: taxpayers, the taxation period, the procedure for determining the taxation object and tax rates, as well as the order of payment and administration of the tax. 
The following persons subject to the state social insurance shall pay solidarity tax:

- employers,

- employees,

- inland employees with an employer/foreigner,

- foreign employees with an employer/foreigner,

- self-employed persons.

The object of solidarity tax shall be the mandatory state social insurance contributions (hereinafter - social contributions), which shall be paid from the income exceeding the maximum amount of social contributions determined by the Cabinet of Ministers. The maximum amount of the object of contributions in 2016 was 48,600 euros. Employers, self-employed persons and other socially insured persons shall make social contributions also from the income that has exceed the maximum amount of contributions from the beginning of the year. Social contributions made from the income that has exceeded the maximum amount of social contributions from the beginning of the year shall be used for solidarity tax. Thus, solidarity tax shall be paid in the form of social contributions by applying social contribution rates and object, as well as complying with the procedures determined for contributing, periods for the submission of reports and making of contributions. Taking into account social contributions declared and made by each particular socially insured person, solidarity tax shall be calculated and transferred to the account of the principal state budget with the State Social Insurance Agency.

\section{Conclusions}

Using the Republic of Latvia experience and the experience of the European Union, we can formulate the following conclusions:

- In modern conditions there is growth in social security contributions. This group of special social payments should be paid great attention to. This refers to the methodological and organizational study of the mechanism of its collection and use, control over its spending and justification of rates.

- It may be necessary and appropriate to apply in Latvia a progressive taxation of personal incomes of the population, i.e. the use of a certain progression according to "big profits - high taxes".

- It is important to use the experience of the Member States of the European Union on the application of differentiated tax rates for taxation of personal incomes.

- It is vital to expand the use of reduced VAT rates in Latvia on the basis of the analysis of the VAT application in the Member States of the European Union for essential goods and socially significant services (exemption from VAT or taxation at a lower rate in this group of goods and services).

- It is important to introduce differentiated non-taxable allowance and the solidarity tax because they are significant factors in the improvement of the personal income tax in Latvia. 


\section{References}

Andreeva T. 2014, Вопросы налоговой политики Латвии. Problems of Economic Policy of the Central and Eastern Europe Countries: Macroeconomic and Regional Aspects, Wydawnictwo Naukowe Uniwersytetu Mikolaja Kopernika, Toruń, pp. 369-383.

Cabinet Regulation № 1 of 05.01.2016 (LV).

https://ec.europa.eu/taxation_customs/sites/taxation/files/docs/body/taxation_paper_58.pdf.

Law "On State Social Insurance" (LV).

Law "On the State Budget for 2016" (LV).

Law "On solidarity tax" (LV).

Social Security Programs Throughout the World: Europe, September 2014, Social Security Administration.

Washington, https://www.ssa.gov/policy/docs/progdesc/ssptw/2014-2015/europe/ssptw14europe.pdf.

Tax Reforms in EU Member States: 2015 Report. Luxembourg: Office for Official Publications of the European Communities, 2015.

VAT Rates Applied in the Member States of the European Union. European Commission, http://ec.europa.eu/taxation_customs/resources/documents/taxation/vat/how_vat_works/rates/vat_rates_en. pdf. 